\title{
Accelerating Economic Development and Improving the Current Account Balance: What Roles can Industrial Policy Play in The Gambia?
}

\author{
Malick M Jallow \\ BSc: International Economics and Trade \\ Nanjing University of Science and Technology, Nanjing, Jiangsu, China
}

Doi:10.19044/esj.2018.v14n34p127 URL:http://dx.doi.org/10.19044/esj.2018.v14n34p127

\begin{abstract}
The Gambia has been running continuous current account deficits since the 1970s owing to large merchandise importation. The GMD (Gambian money dalasi) is on a continuous gradual nose-dive. By employing a vector autoregressive model (VAR) for export determination, and a general to specific linear regression for import determination, for the period 1980-2017 and 1966-2017 respectively, this paper investigates whether the currency depreciation is causing imports (merchandise) to decline and/or causing exports to increase. Furthermore, this article addresses the need and roles industrial policy and industrialization can play in accelerating economic development in The Gambia. The empirical evidence found dictates that a depreciation of the GMD is neither causing a decline in imports nor an increase in exports. Underpinned by the research outcome, we suggest that policymakers implement EOI (export-oriented industrialization) and ISI (imports substitution industrialization) industrialization strategy mix to expedite economic development, correct the long-standing current account deficits and curb the currency depreciation. Given the global economic environment, and the smallness of the Gambia's economy relative to its trading partners, we put forward that the implementation of these strategies is in a framework of engaging the public, private and foreign sectors.
\end{abstract}

Keywords: Industrial policy, industrialization, currency depreciation, exportoriented industrialization, import-substitution industrialization

\section{Introduction}

The third technological revolution that lead to the internationalization of production and contemporary globalization has brought opportunities that could pull many economies out of poverty. Technological advancement in telecommunications and transportation have greatly reduced transaction costs, 
created new jobs and new markets. The impact of globalization can also be visibly seen through the transformation of the "Big Three" (The IMF, World Bank, WTO) in their roles to maintain world economic stability. Multilateral agreement and international economic cooperation saw MNEs (Multinational Enterprises) as movers of production factors, shifting and reallocating production to the most efficient locations. Financial and Capital market liberalization and integration allows capital flows to where it is highly needed and rewarded. The decline in trade barriers and non-trade related barriers (NTBS) through regionalization and trade liberalization regimes, facilitates the movement of goods, services and labor across borders, and help match consumers and suppliers for skills and products improving the living standards of many. These, according to the advocates of globalization, represent an impetus for economic growth and poverty reduction.

Still, one question remains: Are the benefits of globalization equally shared? It would be a deficient analysis if we fail to acknowledge the harsh realities that come with it. The financial crises of the 1990s - the Mexican Peso of 1994, the Asian financial crisis that stemmed out from Thailand, and most recently the 2008 world financial crisis, all remain awful memories still lingering in our minds. National economies are increasingly vulnerable to the effect of technology that instantaneously shifts vast sums of financial capital from one market to another. Stiglitz (2004) explains why capital market liberalization is likelier to lead to economic instability than economic growth. While the IMF is tasked with the role of maintaining global financial and exchange rate stability and help nations facing balance of payments problems, empirical results indicate ambiguity the impact their programs have on members' balance of payments and growth. Riechmann and Stillson (1978) found that IMF programs had no effect on the balance of payments. Results from Pastor (1987b) and Khan (1990) all reported improvements in the balance of payments. Killick (1995) concluded that IMF programs have no effect on the current account. Przeworki and Raymond (2000) used a bivariate dynamic version of the Heckman selection model to arrive at the conclusion that countries under IMF programs experience lower growth rates than countries not under a program.

The multilateral agreement under the WTO has made the use of industrial policy by LDCs (Least Developing Countries) to kick-start industrialization extremely difficult, Bijit Bora et al (2000, UNCTAD No.6). Information asymmetry and power imbalances in international negotiations and international economic organizations not only leave LDCs with one-sided deals but also limits the policy options of these countries. Technology adoption and the catch-up process by LDCs under TRIMS (Trade _Related Investment Measures) and TRIPS (Trade-Related Aspects of Intellectual Property Rights) have been slower than expected under globalization, and 
while the world is embracing the fourth technological revolution, LDCs are yet to fully harness the technology of the third. This hinders not only growth but also widens the inequality between developing and developed countries as it tightens their economic development space. Wade (2003) elaborates on how TRIMS, TRIPS, and GATS under the principles of MFN (most favored nations), none discrimination and national treatment represents the new version of Friedrich list's "kicking away the ladder". Harvard Economist, Richard Friedman noted, "the triumph of globalization and market capitalism has improved living standards for billions while concentrating billions among few".

Over the past decades, economists have attributed industrial policy and industrialization as imperative to economic development, but the use of industrialization strategies in this age of global integration and multilateral agreement such as the WTO is usually complex. Many industrial policy instruments used by NIEs (Newly Industrialized Economies) of East Asia have been abolished after the Uruguay Round of negotiations. Westphal (1990) believes that industrial policy contributed substantially to South Korea's economic success and international competitiveness. Hausmann and Rodrik (2003) mentioned that South Korea and Taiwan made regular use of industrial policies and pointed out that government role is key in nurturing industrial growth and transformation. Nearly all of today's industrialized economies supported substantially and protected their domestic industries through specific interventionist policies and institutions (Emblemsvåg, 2005), and there are no examples of success in economic development in developing countries since 1950 which have not been driven by industrialization, Szirmai (2009, UNU-MERIT). Lall (2013) argues that interventions are profoundly essential to surmount market failures in building capabilities required for industrial development.

Of course, there is no shortage of arguments against industrial policy, opponents of industrial policy often make the arguments such as; the government does not have the complete information to pick winners and determine efficient allocation of resources, and industrial interventions are vulnerable to political capture and corruption. This article will argue that the private sector does not have complete information either and given liberalization has changed the environmental space and rules, many of the traditional industrial policy tools are inapplicable anyway. That is in the $21^{\text {st }}$ century industrial policy should be viewed as strategic collaboration among the private sector including domestic and multinational, and the public sector Rodrik (2004). In other words, the government must re-deploy industrial strategy development in a more effective manner.

As the storms of globalization erode tariff walls of manufacturing, imports by LDCs from developed countries surged while their exports face 
stiff competition in accessing developed economies' markets hampering their export revenues. This has a direct adverse effect on their balance of payments as it creates current account deficits and leads to the depreciation of their currencies. In this paper, we apply a quantitative analysis of data for the period 1966-2017 and 1980-2017 to ascertain the effect depreciation of the GMD (Gambian money dalasi) has on imports and exports. The Gambia like many other Sub-Saharan African nations is a signatory to many international conventions and institutions, notably the IMF, World Bank, and the WTO. Its economy is largely driven by the service sector which constitutes more than 60 percent of the nation's GDP and employs over 50 percent of the labor force. Tourism, the country's mainstay foreign exchange earner plays a key role in driving output in this sector and receives a lot of policy attention. Although the service sector is the largest employer, about half of the population depend on agriculture for their livelihood (World Trade Organization, 2017), which is the second foreign exchange earner. The absence of effective inclusive government policy, lack of capital and technological investment in other sectors, crowds out the effects of linkages among the sectors and leaves the economy vulnerable to external economic upheavals.

The economy is indispensable to politics. The Jammeh era has been marked by fiscal deficits, regular government interference in the management of SOEs (State Owned Enterprises), and mismanagement of state resources which created macroeconomic imbalances, mounting national debt, and loss of investor confidence. In terms of International trade, the country faces current account deficits since 1978 (IMF data), largely associated with high imports. Since merchandise constitutes the bulk share of imports excluding services, this article refers to merchandise imports as total imports and may use these two interchangeably.

The country has a small export base and its export revenue is mainly generated from entrepot trade. Recently, however, The Gambia has been losing its competitive advantage as the regional re-export hub because of rapidly rising efficiency gains in other competing countries, notably in Senegal. The country's monetary authority, CBG (Central Bank of The Gambia) maintains a flexible exchange rate system, thus allowing the determination of the dalasi through the interaction of market forces. Presently, the dalasi is on a continuous gradual nose-dive, and therefore incites my interest and motivates this study in a bid to derive answers as to whether the depreciation of the dalasi is causing exports to increase (positive effect) and/or causing imports to decrease (negative effect) as trade theory would suggest. Moreover, this paper proceeds to address the roles and how a sound and effective industrial policy and industrialization can contribute to accelerating economic development and generate current surpluses. Such structural 
policies although takes time to materialize, are necessary for long-term sustainable development and to strengthen the economy.

\section{Methodology}

\subsection{Data:}

This paper uses time series data for the period 1966-2017 and 19802017 obtained from BIS (Bank for International Settlement) and World Bank. The study utilizes data on imports (merchandise), exports, bilateral exchange rate (average of observation through the period) of the GMD against USD (US dollars), groundnut prices, fish meal prices, and GDP per-capita.

\subsection{Variables:}

The empirical analysis is derived from two distinctive models, exploring data in different various years. An import model consisting of the exchange rate and GDP per-capita as explanatory variables, and imports as the explained variable. On the other hand, the export model consists of exports as the regressed and the exchange rate, GDP per capita of Gambia's top export destination (The EU), groundnut prices and fishmeal prices as the regressors. The main regressor in both models, however, is the exchange rate. The inclusion of groundnut and fishmeal prices in the export model is motivated by the fact that these two are the major agricultural export commodities which makes up the second largest source of foreign exchange for the economy. The consideration of the other variables is in accordance with economic theory.

\subsection{Transformation:}

In other to eliminate trends and non-stationarity, the data is transformed by taking the natural log and then the first difference of the logged variables. To ensure that the variables are stationary, we ran the Augmented Dicky-Fuller (ADF) test on the first difference at the 95 percent confidence level. The results of the ADF test produced t-statistics greater than the 5percent critical value leading us to reject the null hypothesis of nonstationarity. This is an indication that the variables are integrated of the order I (1). In addition to the ADF test, we conducted the Johansen test for cointegration to ascertain the right model specification and regression technique. Evaluating the outcome of the trace and max statistics at the 5percent critical value, the Johansen test results suggest that the variables for the import model are not cointegrated, but the variables of the export model are cointegrated at the maximum rank order of three (3), implying a long-term relationship among them. Since the focus of this research is to determine the short-run dynamic relationship and pass-through effect of the exchange rate on exports primarily, we estimate the VAR on the export variables in levels, given that they are cointegrated, instead of the VECM (Vector error correction 
model) model. Following the Akaike Information Selection Criteria (AIC) outcome, we chose the optimal lag for the export model.

Having differenced the import model variables and ran the selection order criteria, we found no lag relationship among the variables allowing us to estimate the model by simple OLS method. Validated by the pre-estimation tests, we estimate with Stata a Vector autoregressive model (VAR) for export determination and a multiple linear regression model for import determination, in a forward selection method. Although the variables in a VAR model are endogenous, however, given the purpose of our empirical study, our target is to examine the causal and directional (negative or positive) effect of the exchange rate on imports and exports, hence the key regressor.

\subsection{Hypothesis formulation:}

The hypotheses are formulated around the primary variable of interest, the exchange rate.

Import model hypothesis:

$H_{0}$ : the depreciation of the GMD is causing imports to decline (negative relationship)

$H_{1}$ : the depreciation of the GMD is not causing imports to decline (positive relationship).

Export model hypothesis:

$H_{0}$ : the depreciation of the GMD is causing exports to increase (positive relationship)

$H_{1}$ : the depreciation of the GMD is not causing exports to increase (negative relationship)

\subsection{Model Estimation and regression output:}

Import model OLS Estimation: First model

$\Delta l n_{-}$imports $=\beta_{0}+\beta_{1} \Delta l n_{-}$ex_rate $+\beta_{2} \Delta l n_{-} g d p_{-} p e r \_c a p i t a+\varepsilon$

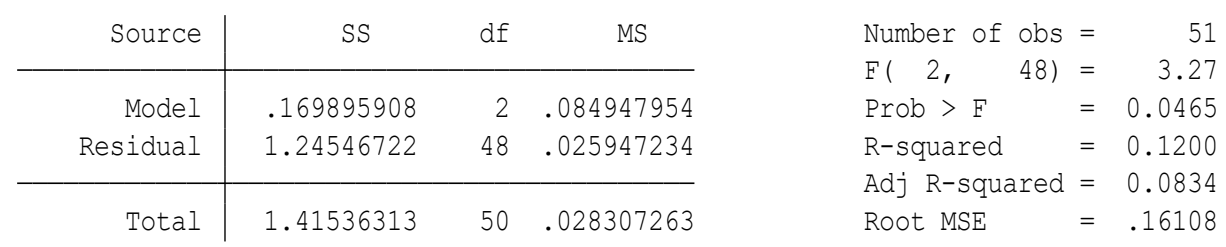

\begin{tabular}{r|rrrrrr}
\hline d_merchnd & Coef. & Std. Err. & $t$ & $\mathrm{P}\rangle|\mathrm{t}|$ & [95\% Conf. Interval] \\
\hline d_ex_rate & -.1583917 & .2213722 & -0.72 & 0.478 & -.6034903 & .2867068 \\
d_gdp_per_capita & .2817487 & .1791337 & 1.57 & 0.122 & -.0784238 & .6419212 \\
_cons & .0625476 & .0287034 & 2.18 & 0.034 & .0048356 & .1202597 \\
\hline
\end{tabular}


Final model:

\begin{tabular}{|c|c|c|c|c|c|}
\hline \multicolumn{6}{|c|}{$\Delta l n_{-}$imports $=\beta_{0}+\beta_{1} \Delta l n_{-} g d p_{-} p e r_{-}$capita $+\varepsilon$} \\
\hline Source & SS & $d f$ & MS & Number of obs & 51 \\
\hline Model & .156612481 & 1 & .156612481 & $\begin{array}{l}\mathrm{F}(1,49) \\
\text { Prob }>\mathrm{F}\end{array}$ & $\begin{array}{r}6.10 \\
0.0171\end{array}$ \\
\hline Residual & 1.25875065 & 49 & .025688789 & R-squared & 0.1107 \\
\hline Total & 1.41536313 & 50 & .028307263 & $\begin{array}{l}\text { Ad] R-square } \\
\text { Root MSE }\end{array}$ & .0992 \\
\hline
\end{tabular}

\begin{tabular}{r|rrrrrr}
\hline d_merchnd & Coef. & Std. Err. & $t$ & P $>|t|$ & & [95\% Conf. Interval] \\
\hline d_gdp_per_capita & .3567864 & .1444997 & 2.47 & 0.017 & .0664034 & .6471694 \\
_cons & .0502171 & .0228396 & 2.20 & 0.033 & .0043193 & .096115 \\
\hline
\end{tabular}

\subsection{Import model empirical results:}

Following a general to a specific model selection process which is based mainly on the values of $t$ and F-statistics, we decide on the final parsimonious model. The general regression output indicates that all the regressors are statistically insignificant and that the population parameters of $\beta_{1}$ and $\beta_{2}$ are not significantly far from zero. However, according to the tstatistic values in absolute terms, the exchange rate is the least significant among the explanatory variables, and by the iterative selection process, we drop the exchange rate and re-run the regression. The resultant of the second regression produces a significant model relative to the first one. Citing the $\mathrm{F}$ and t-statistic values, the final model has an overall significance of 6 percent relative to the 3 percent of the first model, and a significant predictor. In simpler expressions, this interpretation entails that the exchange rate has no impact in any degree to influence the direction of imports, and if construed as the elasticity of demand for imports, the coefficient of the exchange rate (.1583917) signifies an inelastic demand. That is, regardless of how much the currency depreciates, consumers will continue to demand more foreign goods. One explanation as provided by the empirical evidence is the consumers' preference for foreign goods given their gradually rising income. Another reason is the nature of imports, the bulk of which are consumer goods not domestically produced and supplied to the local economy, making their demand a necessity. Conclusively, based on the above grounds, although the directional effect of the exchange rate on imports is negative, it has no statistical significance and hence no real impact on imports. Thus, we reject the null hypothesis of the import model. 


\section{Export determination.}

\section{VAR (3) model estimation and Output}

$$
\begin{aligned}
& \ln \_ \text {export }_{t}=\sigma+\sum_{i=1}^{k} \beta i \ln \_ \text {exrate } t_{-1}+\sum_{\mathrm{j}=1}^{\mathrm{k}} \phi \mathrm{jln} \_f g d p \_ \text {percapita } a_{t-1} \\
& +\sum_{m=1}^{k} \varphi m \ln \_ \text {gnutprices }_{t-1}+\sum_{n=1}^{k} \theta n \ln _{-} \text {fishmealprices }_{t-n} \\
& +u_{1 t} \\
& \ln \_ \text {exrate }_{t}=\alpha+\sum_{i=1}^{k} \beta i \ln \_ \text {exrate }_{t-1}+\sum_{\mathrm{j}=1}^{\mathrm{k}} \phi j \ln \_f g d p_{-} \text {percapita }_{t-1} \\
& +\sum_{m=1}^{k} \varphi m \ln \_ \text {gnutprices }_{t-1}+\sum_{n=1}^{k} \theta n \ln _{-} \text {fishmealprices } \text { is }_{t-1}
\end{aligned}
$$

$\ln \_f g d p_{-} p e r c_{t}=\theta+\sum_{i=1}^{k} \beta i \ln \_$exrate $_{t-1}+\sum_{\mathrm{j}=1}^{\mathrm{k}} \phi \mathrm{jln} \_f g d p_{-}$percapita $_{t-1}$

$$
\begin{aligned}
& +\sum_{m=1}^{k} \varphi m \ln _{-} \text {gnutprices }_{t-1}+\sum_{n=1}^{k} \theta n \ln _{-} \text {fishmealprices }_{t-1} \\
& +u_{3 t}
\end{aligned}
$$

$\ln \_$gnutprice $_{t}=\delta+\sum_{i=1}^{k} \beta i \ln \_$exrate $_{t-1}+\sum_{\mathrm{j}=1}^{\mathrm{k}} \phi \mathrm{j} \ln \_f g d p_{-}$percapita ${ }_{t-1}$

$$
+\sum_{\substack{m=1 \\+u_{4 t}}}^{k} \varphi m \ln _{-} \text {gnutprices }_{t-1}+\sum_{n=1}^{k} \theta n \ln _{-} \text {fishmealprices }_{t-1}
$$

$\ln \_$fishmeal $_{t}=\gamma+\sum_{i=1}^{k} \beta i \ln \_$exrate $_{t-1}+\sum_{\mathrm{j}=1}^{\mathrm{k}} \phi \mathrm{j} \ln _{-} f g d p_{\_}$percapita $_{t-1}$

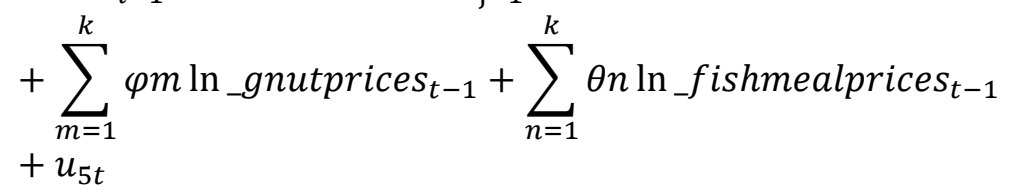


If $g$ is the number of equations for $g$ variables and have $k$ lags of each variable in each equation, the number of estimated parameters is $g+\mathrm{kg}^{\wedge} 2$. Given that $g=5$ and $k=3$, total parameters estimated $=80$. The equations above contain only the first lag of each variable.

\begin{tabular}{|c|c|c|c|c|c|}
\hline \multicolumn{4}{|c|}{ Sample: 1983 - 2017} & \multicolumn{2}{|c|}{ No. of obs } \\
\hline Log likelihood = & 177.05 & & & AIC & \\
\hline FPE & $3.87 e-0$ & & & $\mathrm{HQIC}$ & \\
\hline $\operatorname{Det}($ Sigma_ml $)=$ & $2.78 e-1$ & & & SBIC & \\
\hline Equation & Parms & RMSE & $\mathrm{R}-\mathrm{sq}$ & $\operatorname{chi2}$ & $\mathrm{P}>\operatorname{chi} 2$ \\
\hline In_exports & 16 & .126729 & 0.9131 & 367.6516 & 0.0000 \\
\hline In_ex_rate & 16 & .131547 & 0.9841 & 2159.775 & 0.0000 \\
\hline ln_f_gdp_per_c $\sim a$ & 16 & .08106 & 0.9861 & 2484.921 & 0.0000 \\
\hline ln_gnutprices & 16 & .17927 & 0.7628 & 112.5448 & 0.0000 \\
\hline ln_fishmealpri s & 16 & .170844 & 0.9518 & 690.7648 & 0.0000 \\
\hline
\end{tabular}

\begin{tabular}{|c|c|c|c|c|c|c|}
\hline & Coef. & Std. Err. & $\mathrm{z}$ & $\mathrm{P}>|\mathrm{z}|$ & [95\% Conf. & Interval] \\
\hline \multicolumn{7}{|l|}{ In_exports } \\
\hline L1. & .6696451 & .1296102 & 5.17 & 0.000 & .4156138 & .9236765 \\
\hline L2. & .4841833 & .170729 & 2.84 & 0.005 & .1495607 & .818806 \\
\hline L3. & -.0805849 & .1303662 & -0.62 & 0.536 & -.336098 & .1749282 \\
\hline \multicolumn{7}{|l|}{ ln_ex_rate } \\
\hline L1. & -.401001 & .1599217 & -2.51 & 0.012 & -.7144417 & -.0875603 \\
\hline L2. & -.1972295 & .2471235 & -0.80 & 0.425 & -.6815826 & .2871237 \\
\hline L3. & .1805925 & .1831047 & 0.99 & 0.324 & -.1782862 & .5394711 \\
\hline \multicolumn{7}{|l|}{ In_f_gdp_per_capita } \\
\hline L1. & 1.096215 & .2976011 & 3.68 & 0.000 & .5129278 & 1.679503 \\
\hline L2. & -.6086861 & .3343215 & -1.82 & 0.069 & -1.263944 & .0465721 \\
\hline L3. & -.3148202 & .2745636 & -1.15 & 0.252 & -.852955 & .2233147 \\
\hline \multicolumn{7}{|l|}{ In_gnutprices } \\
\hline L1. & -.288483 & .1596984 & -1.81 & 0.071 & -.601486 & .0245201 \\
\hline L2. & .0493828 & .110424 & 0.45 & 0.655 & -.1670442 & .2658099 \\
\hline L3. & -.6043243 & .1324013 & -4.56 & 0.000 & -.8638261 & -.3448226 \\
\hline \multicolumn{7}{|l|}{ In fishmealprices } \\
\hline L1. & .3636197 & .1321346 & 2.75 & 0.006 & .1046407 & .6225987 \\
\hline L2. & .1521945 & .1127766 & 1.35 & 0.177 & -.0688434 & .3732325 \\
\hline L3. & .1773389 & .1404715 & 1.26 & 0.207 & -.0979802 & .452658 \\
\hline _cons & -.6329027 & 1.84786 & -0.34 & 0.732 & -4.254642 & 2.988836 \\
\hline
\end{tabular}




\begin{tabular}{|c|c|c|c|c|c|c|}
\hline \multicolumn{7}{|l|}{$\begin{array}{l}\text { In_ex_rate } \\
\text { ln_exports }\end{array}$} \\
\hline L1. & .323614 & .1345373 & 2.41 & 0.016 & .0599257 & .5873023 \\
\hline L2. & -.2903367 & .1772192 & -1.64 & 0.101 & -.63768 & .0570065 \\
\hline L3. & -.0195198 & .1353221 & -0.14 & 0.885 & -.2847462 & .2457065 \\
\hline \multicolumn{7}{|l|}{ In_ex_rate } \\
\hline L1. & 1.114034 & .1660011 & 6.71 & 0.000 & .7886783 & 1.43939 \\
\hline L2. & .1471259 & .2565178 & 0.57 & 0.566 & -.3556398 & .6498916 \\
\hline L3. & -.1434108 & .1900654 & -0.75 & 0.451 & -.5159322 & .2291105 \\
\hline \multicolumn{7}{|l|}{ ln_f_gdp_per_capita } \\
\hline L1. & -.511091 & .3089144 & -1.65 & 0.098 & -1.116552 & .0943701 \\
\hline $\mathrm{L} 2$. & -.1453686 & .3470307 & -0.42 & 0.675 & -.8255363 & .5347991 \\
\hline L3. & .45062 & .2850011 & 1.58 & 0.114 & -.1079719 & 1.009212 \\
\hline \multicolumn{7}{|l|}{ In_gnutprices } \\
\hline L1. & .0099985 & .1657693 & 0.06 & 0.952 & -.3149033 & .3349004 \\
\hline L2. & -.041107 & .1146217 & -0.36 & 0.720 & -.2657615 & .1835475 \\
\hline L3. & .024558 & .1374345 & 0.18 & 0.858 & -.2448087 & .2939247 \\
\hline \multicolumn{7}{|l|}{ ln_fishmealprices } \\
\hline L1. & -.0579192 & .1371577 & -0.42 & 0.673 & -.3267432 & .2109049 \\
\hline L2. & -.0751983 & .1170637 & -0.64 & 0.521 & -.304639 & .1542424 \\
\hline L3. & .0803463 & .1458115 & 0.55 & 0.582 & -.205439 & .3661316 \\
\hline${ }^{\text {cons }}$ & 1.953147 & 1.918106 & 1.02 & 0.309 & -1.806271 & 5.712566 \\
\hline \multicolumn{7}{|l|}{$\begin{array}{r}\text { ln_f_gdp_per_capita } \\
\text { ln_exports }\end{array}$} \\
\hline L1. & .1104266 & .0829032 & 1.33 & 0.183 & -.0520607 & .2729139 \\
\hline L2. & -.1379683 & .1092042 & -1.26 & 0.206 & -.3520046 & .076068 \\
\hline L3. & -.069268 & .0833868 & -0.83 & 0.406 & -.2327031 & .094167 \\
\hline \multicolumn{7}{|l|}{ In_ex_rate } \\
\hline L1. & .1813328 & .1022915 & 1.77 & 0.076 & -.0191548 & .3818204 \\
\hline L2. & .1065939 & .1580688 & 0.67 & 0.500 & -.2032152 & .4164031 \\
\hline L3. & .0825593 & .1171201 & 0.70 & 0.481 & -.146992 & .3121106 \\
\hline \multicolumn{7}{|l|}{ ln_f_gdp_per_capita } \\
\hline L1. & .5817442 & .1903561 & 3.06 & 0.002 & .2086532 & .9548352 \\
\hline L2. & -.4831183 & .2138437 & -2.26 & 0.024 & -.9022443 & -.0639924 \\
\hline L3. & .4831868 & .1756205 & 2.75 & 0.006 & .138977 & .8273966 \\
\hline \multicolumn{7}{|l|}{ ln_gnutprices } \\
\hline L1. & .1015999 & .1021487 & 0.99 & 0.320 & -.0986078 & .3018076 \\
\hline L2. & .1196699 & .070631 & 1.69 & 0.090 & -.0187643 & .2581042 \\
\hline L3. & -.0518009 & .0846885 & -0.61 & 0.541 & -.2177873 & .1141855 \\
\hline \multicolumn{7}{|l|}{ ln_fishmealprices } \\
\hline L1. & -.0646436 & .0845179 & -0.76 & 0.444 & -.2302956 & .1010084 \\
\hline L2. & -.0509358 & .0721358 & -0.71 & 0.480 & -.1923194 & .0904478 \\
\hline L3. & -.1425631 & .0898505 & -1.59 & 0.113 & -.3186668 & .0335406 \\
\hline Cons & 5.565534 & 1.181956 & 4.71 & 0.000 & 3.248943 & 7.882124 \\
\hline
\end{tabular}




\begin{tabular}{|c|c|c|c|c|c|c|}
\hline \multicolumn{7}{|l|}{$\begin{array}{l}\text { ln_gnutprices } \\
\text { ln exports }\end{array}$} \\
\hline L1. & .3792884 & .1833456 & 2.07 & 0.039 & .0199376 & .7386392 \\
\hline $\mathrm{L} 2$. & -.1860768 & .241512 & -0.77 & 0.441 & -.6594316 & .2872779 \\
\hline L3. & -.277504 & .1844151 & -1.50 & 0.132 & -.6389509 & .0839429 \\
\hline \multicolumn{7}{|l|}{ ln_ex_rate } \\
\hline L1. & -.3792548 & .226224 & -1.68 & 0.094 & -.8226457 & .0641361 \\
\hline $\mathrm{L} 2$. & .8339734 & .349579 & 2.39 & 0.017 & .148811 & 1.519136 \\
\hline L3. & -.4075576 & .2590186 & -1.57 & 0.116 & -.9152246 & .1001095 \\
\hline \multicolumn{7}{|l|}{ ln_f_gdp_per_capita } \\
\hline L1. & .3862374 & .4209844 & 0.92 & 0.359 & -.4388767 & 1.211352 \\
\hline $\mathrm{L} 2$. & -1.350224 & .4729288 & -2.86 & 0.004 & -2.277148 & -.4233012 \\
\hline L3. & 1.037987 & .3883957 & 2.67 & 0.008 & .2767454 & 1.799228 \\
\hline \multicolumn{7}{|l|}{ In_gnutprices } \\
\hline L1. & .2428386 & .2259082 & 1.07 & 0.282 & -.1999333 & .6856104 \\
\hline L2. & -.1092661 & .156205 & -0.70 & 0.484 & -.4154222 & .19689 \\
\hline $\mathrm{L} 3$. & .0969145 & .1872939 & 0.52 & 0.605 & -.2701748 & .4640038 \\
\hline \multicolumn{7}{|l|}{ ln_fishmealprices } \\
\hline L1. & -.033009 & .1869166 & -0.18 & 0.860 & -.3993588 & .3333408 \\
\hline $\mathrm{L} 2$. & .4394655 & .1595329 & 2.75 & 0.006 & .1267868 & .7521442 \\
\hline $\mathrm{L} 3$. & -.2548311 & .19871 & -1.28 & 0.200 & -.6442954 & .1346333 \\
\hline _cons & 5.12755 & 2.613969 & 1.96 & 0.050 & .0042649 & 10.25084 \\
\hline \multicolumn{7}{|l|}{ In_fishmealprices } \\
\hline L1. & -.2124667 & .1747278 & -1.22 & 0.224 & -.5549268 & .1299934 \\
\hline $\mathrm{L} 2$. & -.5456509 & .2301601 & -2.37 & 0.018 & -.9967563 & -.0945454 \\
\hline L3. & .0732942 & .1757469 & 0.42 & 0.677 & -.2711635 & .4177518 \\
\hline \multicolumn{7}{|l|}{ In_ex_rate } \\
\hline- L1. & .4465624 & .2155907 & 2.07 & 0.038 & .0240124 & .8691125 \\
\hline L2. & .1042587 & .3331476 & 0.31 & 0.754 & -.5486987 & .7572161 \\
\hline L3. & -.3398858 & .2468438 & -1.38 & 0.169 & -.8236908 & .1439191 \\
\hline \multicolumn{7}{|l|}{ ln_f_gdp_per_capita } \\
\hline L1. & -.3372206 & .4011967 & -0.84 & 0.401 & -1.123552 & .4491105 \\
\hline $\mathrm{L} 2$. & .5980054 & .4506995 & 1.33 & 0.185 & -.2853494 & 1.48136 \\
\hline L3. & .2820177 & .3701398 & 0.76 & 0.446 & -.4434429 & 1.007478 \\
\hline \multicolumn{7}{|l|}{ In gnutprices } \\
\hline L1. & .440716 & .2152897 & 2.05 & 0.041 & .0187559 & .862676 \\
\hline L2. & .4463977 & .1488628 & 3.00 & 0.003 & .154632 & .7381635 \\
\hline L3. & .2680902 & .1784905 & 1.50 & 0.133 & -.0817447 & .6179251 \\
\hline \multicolumn{7}{|l|}{ ln_fishmealprices } \\
\hline L1. & .3413789 & .1781309 & 1.92 & 0.055 & -.0077513 & .690509 \\
\hline $\mathrm{L} 2$. & -.2682907 & .1520343 & -1.76 & 0.078 & -.5662724 & .029691 \\
\hline L3. & -.0051271 & .1893699 & -0.03 & 0.978 & -.3762853 & .3660311 \\
\hline Cons & 5.076827 & 2.491104 & 2.04 & 0.042 & .1943532 & 9.9593 \\
\hline
\end{tabular}


Granger causality Wald tests

\begin{tabular}{|c|c|c|c|c|}
\hline Equation & Excluded & chi2 & $d f$ & Prob $>$ chi2 \\
\hline In_exports & In_ex_rate & 17.199 & 3 & 0.001 \\
\hline ln_exports & ln_f_gdp_per_ca a & 13.772 & 3 & 0.003 \\
\hline ln_exports & In_gnutprices & 23.072 & 3 & 0.000 \\
\hline In exports & ln fishmealprices & 16.401 & 3 & 0.001 \\
\hline ln_exports & ALL & 51.026 & 12 & 0.000 \\
\hline In_ex_rate & In_exports & 6.0624 & 3 & 0.109 \\
\hline ln ex rate & ln $f$ gdp per ca a & 4.3657 & 3 & 0.225 \\
\hline In ex rate & In gnutprices & .19064 & 3 & 0.979 \\
\hline In ex rate & ln fishmealprices & 1.4357 & 3 & 0.697 \\
\hline In_ex_rate & ALL & 19.408 & 12 & 0.079 \\
\hline In_f_gdp_per_ca a & In_exports & 4.3508 & 3 & 0.226 \\
\hline ln_f_gdp_per_ca a & In_ex_rate & 20.197 & 3 & 0.000 \\
\hline ln_f_gdp_per_ca a & ln_gnütprices & 5.5508 & 3 & 0.136 \\
\hline ln_f_gdp_per_ca a & ln_fishmealprices & 5.0323 & 3 & 0.169 \\
\hline ln_f_gdp_per_ca a & ALL & 39.114 & 12 & 0.000 \\
\hline In_gnutprices & In_exports & 6.5422 & 3 & 0.088 \\
\hline In_gnutprices & In_ex_rate & 6.1022 & 3 & 0.107 \\
\hline ln_gnutprices & ln_f_gdp_per_ca a & 10.547 & 3 & 0.014 \\
\hline In_gnutprices & ln_fishmealprices & 9.331 & 3 & 0.025 \\
\hline ln_gnutprices & ALL & 43.543 & 12 & 0.000 \\
\hline ln fishmealprices & In_exports & 19.933 & 3 & 0.000 \\
\hline ln fishmealprices & In ex rate & 7.7546 & 3 & 0.051 \\
\hline ln fishmealprices & ln_f_gdp_per_ca a & 8.198 & 3 & 0.042 \\
\hline ln fishmealprices & In gnutprices & 10.959 & 3 & 0.012 \\
\hline ln_fishmealprices & ALL & 42.132 & 12 & 0.000 \\
\hline
\end{tabular}

\section{Impulse-response function and forecast error variance decomposition:}

Results from varbasic

\begin{tabular}{|l|lll|lll|}
\hline & \multicolumn{1}{|c}{$\begin{array}{c}(1) \\
\text { irf }\end{array}$} & $\begin{array}{c}(1) \\
\text { Lower }\end{array}$ & $\begin{array}{c}(1) \\
\text { Upper }\end{array}$ & $\begin{array}{c}(1) \\
\text { fevd }\end{array}$ & \multicolumn{1}{c|}{$\begin{array}{c}(1) \\
\text { Lower }\end{array}$} & $\begin{array}{c}(1) \\
\text { Upper }\end{array}$ \\
\hline 0 & 0 & 0 & 0 & 0 & 0 & 0 \\
1 & -.401001 & -.714442 & -.08756 & 0 & 0 & 0 \\
2 & -.44192 & -.895757 & .011918 & .02875 & -.058198 & .115697 \\
3 & -.556421 & -1.16337 & .05053 & .045071 & -.07691 & .167052 \\
4 & -.175814 & -.781709 & .430081 & .073181 & -.111566 & .257928 \\
5 & -.158452 & -.693836 & .376931 & .071159 & -.121264 & .263582 \\
6 & .042421 & -.455316 & .540159 & .072563 & -.126829 & .271954 \\
7 & .122017 & -.36191 & .605944 & .072424 & -.1242 & .269048 \\
8 & .162254 & -.298326 & .622834 & .073888 & -.123347 & .271124 \\
\hline
\end{tabular}



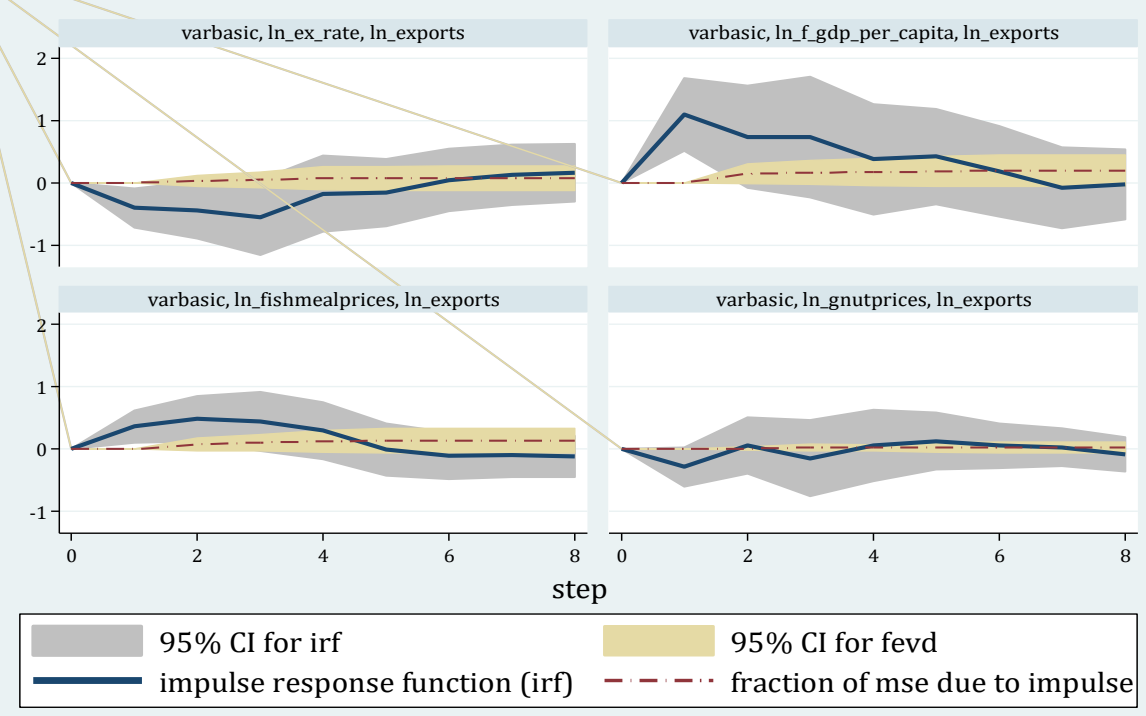

Graphs by irfname, impulse variable, and response variable varbasic, In_f_gdp_per_capita, In_exports

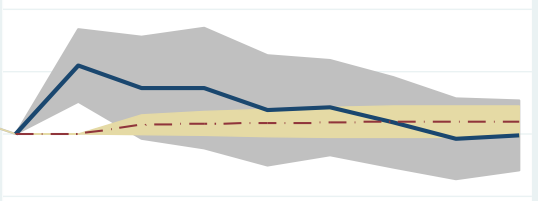

varbasic, ln_gnutprices, ln_exports

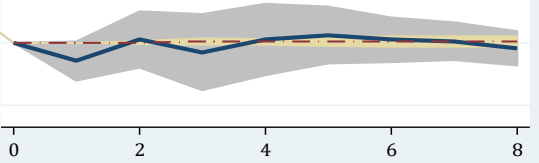

$95 \%$ CI for fevd

fraction of mse due to impulse

\subsection{Export model empirical results:}

The analysis of the VAR model output is concentrated on the first section where export is regressed and the exchange rate and other variables are the regressors. Collectively, the z-statistics of the coefficients are displaying ambiguous signals making the interpretation of the of the VAR difficult. Restrictively, if we focus on the first lagged coefficients, all the regressors are statistically significant except for groundnut prices (nut prices). Accordingly, there is a significant negative relationship between the exchange rate and exports, implying that if the exchange rate increases (further depreciation of the GMD) say by 1 percent in a year prior (t-1), we would expect exports to approximately decline by 40 percent in the coming year $(\mathrm{t}+1)$.

The Granger causality test also affirms that there is a unidirectional causality running from the exchange rate to exports, while the sign of the coefficient tells the degree (positive or negative) of the impact. In fact, all the explanatory variables granger causes the explained variable and the VAR model is significant overall and stable. Having understood the VAR model is a-theoretic, and to better evaluate the impact of the exchange rate on exports, we generated the irf (impulse-response function) and the fevd (forecast error variance decomposition) graph and tabular results for a period of eight years (denoted by step). The tabular and graphical outcome of the irf and fevd explicitly suggest that the initial response of exports to a standard deviation shock in the exchange rate is negative, which lasts for about a period of five 
years before shifting response and dissipating. Of the cumulative response and pass through effect, the exchange rate accounts for 7.3 percent maximum, a minimum of zero in the first year and an average of 5.5\%. A compelling question, however, is why exports decline or why the response of exports to depreciation negative? It is crucial to note that while the Gambia exports agricultural products like groundnut, it remains a net importer of mechanical equipment, fertilizer, cereals, and other necessary materials. Therefore, a depreciation of the GMD increases the cost of acquiring production inputs. Moreover, agricultural output relies heavily on rainfall in many developing countries, the Gambia inclusive, which is not captured in our model. Given the global climate change, rainfall has been irregular, and, in some cases, the country experienced a mild drought or shorter rainy season. Finally, in contradiction to trade theory, this empirical evidence signals the necessity for an intervention to improve the export commodity structure, expand the export base and revenue. It also hints that it is not a sound policy to rely on the depreciating currency to stimulate export growth given the nature of the country's export structure.

\section{Discussion:}

It is tempting and may be theoretically right to suggest that the Gambia is a developing country and needs capital goods and technology to develop its infrastructure which it cannot produce therefore leading to high imports. This explanation may be valid in some cases; however, the reason could also be that the goods imported are not domestically produced and are essential basic commodities which make domestic consumers irresponsive to price changes (exchange rate in this case), causing the exchange rate to be insignificant in determining the direction of imports. Evidently, the Gambia has been running current account deficits owing to large deficits in its merchandise trade rather than technology and capital goods importation. Even though presidential directives were issued to the CBG to maintain the dalasi to the dollar exchange rate between GMD/USD 35-40 in 2015, it has not done much to prevent the gradual decline of the currency (World Trade Organization, 2017). The country exports primary products mainly dominated by groundnut, cashew nuts, and fish which face stiff competition and prone to price fluctuations in the world market and natural disasters, such as drought and erratic rainfall.

According to the Prebisch-Singer hypothesis, the terms of trade of commodity export-reliant economies are likely to deteriorate in the long-run because of the decline of primary commodity prices (United Nations Conference on Trade and Development, 2017). Government revenue in commodity export-reliant economies is closely linked to commodity prices, and thus a negative shock on commodity prices can cause economic disruptions, put pressure on international reserves especially where imports 
overwhelmingly outstrip exports and create fiscal balance disturbances forcing a government to restructure public spending plans thereby hindering economic development and poverty alleviation. Wholesale and retail services are the top performers of the service sector and have averaged 21.5 percent from 20102016. This is another clear manifestation that the economy depends so much on imports to the extent that many are engaged in trading rather than productive activities. The economic performance of the two major sources of foreign exchange and engines of growth which are tourism and agricultural sectors are affected by seasonal changes which impact output and employment. One way the government could address this issue to accelerate growth is to ensure year-round agricultural production and tourism by providing incentives to stimulate investment in capital and technology in these sectors. Another viable and long-term sustainable strategy which this paper proposes is the application of industrial policy and industrialization through the manufacturing sector.

Manufacturing sector's share of GDP is 5-6 percent, it has been neglected and receives no attention from policymakers. Industrialization is a critical tool in poverty eradication, employment creation, and spurs technological advancement, and productivity gains. (Thirlwall \& Cornwall, 1979) argued that manufacturing is the locale for technological progress. By engaging in the production of simple and inexpensive manufactured products, the Gambia diversifies its economy and reduces its susceptibleness to exogenous economic shocks. Igniting a new engine of growth will provide employment opportunities to youths and graduates especially those leaving vocational and technical training institutions. As both their incomes and output flows back into the local economy, it creates a multiplier effect and generates growth. A country's failure to develop its domestic manufacturing industry will result in increasing importation of goods Szirmai (2009, UNU-MERIT).

Although this paper has identified and discussed some of the challenges LDCs face in the era of globalization when it comes to the use of industrial policy, they do not qualify as a rationale for isolation from the global economy. Instead, policymakers should re-think industrial policy not as government spelling out directives choosing winners and losers, but as a discovery process where private firms both domestic and multinational, and the government engages in strategic collaboration to learn about underlying costs and opportunities and engage in strategic coordination Rodrik (2004). What obstructs such logical and effective policy even in the face of globalization is the willingness of the government to deploy it not its ability to do so.

The EU, China, Brazil, India, and Senegal are the top trading partners of The Gambia. The Gambia is obviously a small economy relative to its trading partners and to the world, which makes it a price taker. The size of the 
economy embodies the potential opportunity that The Gambia can exploit without hurting its partners and violate multilateral treaties, the opportunity I call "the advantage of smallness". Through bilateral negotiations, The Gambia could establish double taxation treaties and BITs (Bilateral Investment Treaties) to prevent nationalization and expropriation of foreign firms. Coupled with other incentives, it could encourage and attract foreign direct investment from trading partners to its export sector and/or engage in processing trade. The presence of FDI in the export sector expands the export and revenue bases of the economy, improve export quality as well as introduce foreign technology that the country desperately needs. FDI, if directed to productive sectors generates growth, creates employment and remains an important vehicle for technology diffusion through knowledge spillovers as concluded by Silajdzic and Mehic (2015), Branstetter (2006). In return, The Gambia could raise taxes on the importation of specific simple products such as foodstuff, beverages, clothing, and furniture, while directing and influencing the importation of capital goods for the development of domestic industries. This is export-oriented industrialization (EOI) and Import substitution industrialization (ISI) strategy mix. Zhu (2006) presents the argument that both Taiwan and Mainland China have implemented the combination of EOI-ISI development strategies in their entire miracle period. Traditionally, ISI involves heavy government intervention in the provision and allocation of economic resources, this may not be feasible in the case of The Gambia since the government faces huge financial constraints.

However, the ISI strategy could be implemented not through SOEs but through private indigenous and domestic investment. By providing an aggressive incentive program, The Gambia motivates its citizens and diaspora to invest in the economy. For those abroad, it means converting their remittances which is a major source of foreign exchange and use their expertise, to invest in more productive activities and earn high returns while contributing to national development. This strategy frees resources and allows the government to shift its attention to monitoring implementation and development of infrastructure, R\&D policy, strengthen institutions to prevent rent-seeking and corruption, as well as reduce pressure on commercial banks' lending rates by cutting deficits and crowed-in the private sector. Less government intervention ensures fiscal discipline and avoids monetization of debt which spurs currency and debt crises, the typical results of a failed ISI strategy as research evidence shows in the Peso crisis of 1994. If effectively implemented, these strategies could provide international reserves through current account surpluses which helps to cushion the economy against economic misfortunes. Implementation of ISI through indigenization and private investment, allows government to re-direct its limited resources to provide education, health, energy, and efficient transportation systems among 
others, especially education as Borensztein et al (1998) concluded that higher productivity of FDI will only be fully harnessed when the recipient country has a certain threshold of human capital stock.

\section{Conclusion:}

Technological innovation and global economic integration have shrunken geographical distances and boost trade between nations. As the waves of globalization swept across countries, it did not only propel nations into prosperity, but it also changed the rules of the game which broadened the impediments for lagging economies to catch-up. This scenario is in total contradiction to the expectations. In the presence of increasing multilateral, bilateral and regional agreements, the economic miracle enjoyed by the East Asian Tigers is hard if not impossible to come by. Industrial policy and industrialization which have proven useful in kicking-off economic growth and development have been given no chance for implementation in the $21^{\text {st }}$ century, as most agreements seek to eliminate any use of such policies.

Trade theory maintains that depreciation of a nation's currency tends to improve its current account balance in the long-run. According to this theory, exports are expected to rise, and imports are expected to decline when a country's currency depreciates. This article sets to enquire such theory focusing its empirical analysis on The Gambia. The outcome of the empirical exercise contradicts the study hypotheses. Evidence provided by the empirical results proves that a depreciation of the GMD has no effect in any degree to influence the behavior of imports. In other words, this means, if the status quo persists, the ailing currency will not cause a shift in the direction of imports nor does it lead to export growth. In fact, the results depict a negative response of exports to a standard deviation shock in the exchange rate. This does not necessarily nullify the trade theory, but it points out the importance of the composition of imports and exports.

Substantiated by the research findings, the output of this paper is a signal to policymakers that there is evidence which suggests the need for strategic government intervention to steer the economy off its current course. The significant negative response of exports to the exchange rate is testimony that depending on the ailing currency to boost export is risky and remaining a commodity export-dependent country will not create the needed current account surpluses.

Finally, we suggest policymakers make structural reforms to steer the economy off its current trajectory. Although the world economic engagement rules have contracted the space for the use of industrial policy tools, there still exist exploitable loopholes. Therefore, this paper proposes a long-term sustainable strategy of industrialization and industrial policy in the form of EOI-ISI strategy mix. Having considered the global environment, the 
Gambia's commitment to international conventions and agreements, and the relative size of its economy to its trading partners, the implementation of these strategies should be in a framework that engages the public, private (both at home and abroad) and foreign sectors. In addition, policymakers should also pay ample attention to the manufacturing sector to ignite the third engine of growth, this will help reduce import dependence, curb the currency depreciation and reduce economic exposure.

\section{References:}

1. Bora, B., Lloyd, P., \& Pengestu, M. (2000). Industrial Policy and the WTO. The World Economy, 23(4), 543-559. doi: 10.1111/14679701.00289

2. Borensztein, E., De Gregorio, J., \& Lee, J. (1998). How does foreign direct investment affect economic growth? Journal of International Economics, 45(1), 115-135. doi: 10.1016/s0022-1996(97)00033-0

3. Branstetter, L. (2006). Is foreign direct investment a channel of knowledge spillovers? Evidence from Japan's FDI in the United States. Journal of International Economics, 68(2), 325-344. doi: 10.1016/j.jinteco.2005.06.006

4. Emblemsvåg, J. (2005). Kicking away the Ladder: Development Strategy in Historical Perspective20053H.-J. Chang. Kicking away the Ladder: Development Strategy in Historical Perspective. London: Anthem Press 2002. On the Horizon, 13(3), 186-191. doi: $10.1108 / 10748120510618222$

5. Hausmann, R., \& Rodrik, D. (2003). Economic development as selfdiscovery. Journal of Development Economics, 72(2), 603-633. doi: 10.1016/s0304-3878(03)00124-X

6. Khan, M. (1990). The Macroeconomic Effects of Fund-Supported Adjustment Programs. Staff Papers-International Monetary Fund, 37(2), 195. doi: 10.2307/3867289

7. Lall, S. (2013). "Reinventing Industrial Strategy: The Role of Government Policy in Building Industrial Competitiveness. Annals of Economics and Finance, Society For AEF, 14(2), 785-829.

8. Logan, B., \& Killick, T. (1997). IMF Programmes in Developing Countries: Design and Impact. Economic Geography, 73(2), 264. doi: $10.2307 / 144455$

9. Pastor, M. (1987). The effects of IMF programs in the Third World: Debate and evidence from Latin America. World Development, 15(2), 249-262. doi: 10.1016/0305-750x(87)90080-5

10. Przeworski, A., \& Vreeland, J. (2000). The effect of IMF programs on economic growth. Journal of Development Economics, 62(2), 385421. doi: 10.1016/s0304-3878(00)00090-0 
11. Reichmann, T., \& Stillson, R. (1978). Experience with Programs of Balance of Payments Adjustment: Stand-by Arrangements in the Higher Tranches, 1963-72 (Les programmes d'ajustement de la balance des paiements: accords de confirmation dans les tranches superieures, 1963-72) (Analisis de programas de ajuste de balanza de pagos: Acuerdos de derecho de giro en los tramos superiores, 196372). Staff Papers - International Monetary Fund, 25(2), 293. doi: $10.2307 / 3866704$

12. Rodrik, D. (2004). Industrial Policy for the Twenty-First Century. SSRN Electronic Journal. doi: 10.2139/ssrn.617544

13. Silajdzic, S., \& Mehic, E. (2015). Knowledge Spillovers, Absorptive Capacities and the Impact of FDI on Economic Growth: Empirical Evidence from Transition Economies. Procedia - Social and Behavioral Sciences, 195, 614-623. doi: 10.1016/j.sbspro.2015.06.142

14. Stiglitz, J. (2004). Capital-market Liberalization, Globalization, and the IMF. Oxford Review of Economic Policy, 20(1), 57-71. doi: 10.1093/oxrep/20.1.57

15. Szirmai, A. (2012). Industrialization as an engine of growth in developing countries, 1950-2005. Structural Change and Economic Dynamics, 23(4), 406-420. doi: 10.1016/j.strueco.2011.01.005

16. Thirlwall, A., \& Cornwall, J. (1979). Modern Capitalism: Its Growth and Transformation. Economica, 46(181), 94. doi: 10.2307/2553105

17. United Nations Conference on Trade and Development. (2017). Commodities and Development Report 2017: Commodity Markets, Economic Growth and Development (p. 26).

18. World Trade Organization. (2017). Trade Policy Review: The Gambia (pp. 8, 13).

19. Wade, R. (2003). What strategies are viable for developing countries today? The World Trade Organization and the shrinking of 'development space'. Review of International Political Economy, 10(4), 621-644. doi: 10.1080/09692290310001601902

20. Westphal, L. (1990). Industrial Policy in an Export-Propelled Economy: Lessons from South Korea's Experience. Journal of Economic Perspectives, 4(3), 41-59. doi: 10.1257/jep.4.3.41

21. Zhu, T. (2006). Rethinking Import-Substitution industrialization: Development Strategies and Institutions in Taiwan and China. United Nations University-World Institute for Development Economics Research, 2006/76. 